\title{
Influence of the resistive-pulse welding parameters of nickel super-alloys on selected properties of the connection
}

\author{
Wpływ parametrów spawania opornościowo-impulsowego \\ superstopów niklu na wybrane właściwości połączenia
}

\author{
SŁAWOMIR SPADŁO \\ WOJCIECH DEPCZYŃSKI \\ PIOTR MŁYNARCZYK \\ TADEUSZ GAJEWSKI \\ JAROSŁAW DĄBROWA *
}

DOI: https://doi.org/10.17814/mechanik.2017.11.180

\begin{abstract}
Microstructure and mechanical tests of welds of thin sheets made from nickel-based super-alloys (Haynes 230 and Hastelloy X) were presented. The welds were made using the resistive-pulse micro-welding method using the WS $7000 \mathrm{~S}$ device. The micro-hardness of the joints was measured with a Matsuzawa Vickers MX 100 hardness tester at 100 G $(0.98$ $\mathrm{N})$. Metallographic observations of the prepared microsections were performed using the Nikon Eclipse MA200 optical microscope at various magnifications. The metallographic microstructure studies were supplemented by linear analysis of the chemical composition, for which the OXFORD X-MAX electron microscope was applied.
\end{abstract}

KEYWORDS: micro-welding, surface engineering, microstructure, micro-hardness

Resistive-pulse welding [1, 2, 4], called micro-welding (as a result of the impact on bonded materials), is characterized by the fact that high-energy discharge in the short term produces a local rise in a temperature above the solidus line. Due to the physical phenomena accompanying the bonding process, the welded material is connected indirectly between the sealing and welding. Micro-welding is used where, due to the small size of the bonding (or micro-gripping) area, traditional techniques would be ineffective. Resistive-pulse welding is suitable for a much wider range of repairs than traditional regeneration methods [5-16]. This technique has gained a lot of popularity. Although the micro-seam yields in terms of the quality of classic weld, due to its negligible thermal impact on the substrate material, ease of processing, and the applicability of the components for quick and relatively easy repair of the components, is

\footnotetext{
* Dr hab. inż. Sławomir Spadło, prof. PŚk (sspadlo@tu.kielce.pl), dr inż. Wojciech Depczyński (wdep@tu.kielce.pl), mgr inż. Piotr Młynarczyk(piotrm@tu.kielce.pl) - Zakład Materiałoznawstwa i Technologii Amunicji Politechniki Świętokrzyskiej; mgr inż. Tadeusz Gajewski (t.gajewski@mesko.com.pl) - Centrum Innowacji i Wdrożeń Grupy Amunicyjno-Rakietowej PGZ, Mesko S.A.; mgr inż. Jarosław Dąbrowa (j.dąbrowa@mesko.com.pl) - Mesko S.A.
}

valid in many different cases - e.g. in repairing local damage to the dies, injection molds or cutting edges. The commercially available micro-welding devices have impulse parameters indicating the possibility of producing thin sheet metal connections made of $\mathrm{Ni}$-based superalloys. In literature, the results of investigations of such connections are increasingly found [17-28].

\section{Research equipment and subject of study}

The resistive-pulse micro-welding was performed using a WS 7000 S welding machine from SST France \& Vision Lasertechnik. The device generates pulses with an average frequency of $5000 \mathrm{~Hz}$. Analyses of preliminary results have allowed to determine the conditions of micro-welding of thin sheets made of Hastelloy $X$ and Haynes 230 super-alloys.

The following settings have been made:

- welding current intensity in the range of $50 \div 70 \%$ of power (maximum $7000 \mathrm{~A}$ ),

- welding time $10 \mathrm{~ms}$,

- pulse form - continuous,

- working cycle - welding cycle, many pulses.

The chemical composition of the tested super-alloys is shown in tables I and II.

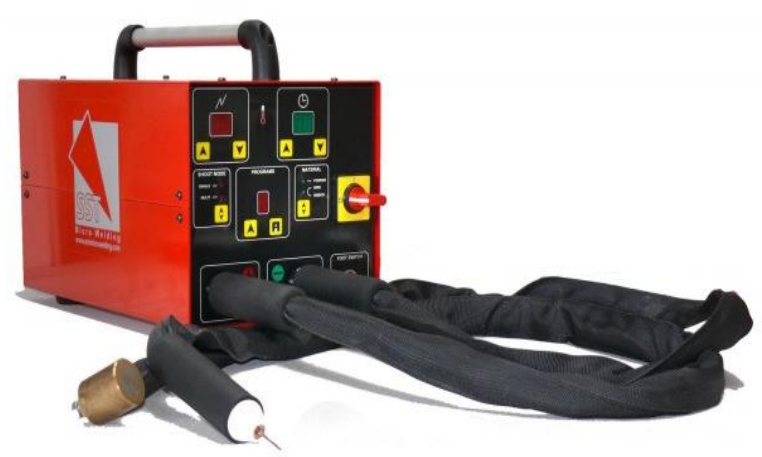

Fig. 1. Pulse micro-welding device WS 7000 S 
TABLE I. Chemical composition of Hastelloy $X$ superalloy

\begin{tabular}{|c|c|}
\hline Element & Content, \% \\
\hline $\mathrm{Ni}$ & 47 \\
\hline $\mathrm{Cr}$ & 22 \\
\hline $\mathrm{Fe}$ & 18 \\
\hline $\mathrm{Mo}$ & 9 \\
\hline $\mathrm{Co}$ & 1.5 \\
\hline $\mathrm{W}$ & 0.6 \\
\hline $\mathrm{C}$ & 0.1 \\
\hline $\mathrm{Mn}$ & 1.0 \\
\hline $\mathrm{Si}$ & 1.0 \\
\hline $\mathrm{B}$ & 0.008 \\
\hline
\end{tabular}

TABLE II. Chemical composition of Haynes 230 super-alloy

\begin{tabular}{|c|c|c|}
\hline \multirow{2}{*}{ Element } & \multicolumn{2}{|c|}{ Content, \% } \\
\cline { 2 - 3 } & minimum & maximum \\
\hline $\mathrm{Ni}$ & 47 & 65 \\
\hline $\mathrm{Cr}$ & 20 & 24 \\
\hline $\mathrm{W}$ & 13 & 15 \\
\hline Mo & 1.0 & 3 \\
\hline Co & - & 5 \\
\hline $\mathrm{Al}$ & 0.2 & 0.5 \\
\hline La & 0.005 & 0.005 \\
\hline Mn & 0.3 & 1 \\
\hline C & 0.05 & 0.15 \\
\hline Si & 0.25 & 0.75 \\
\hline
\end{tabular}

\section{Metallographic microstructure of a joint}

In order to carry out the metallographic examination of the joint, the specimens were cut off and included in the resin and then prepared for metallographic deposition.

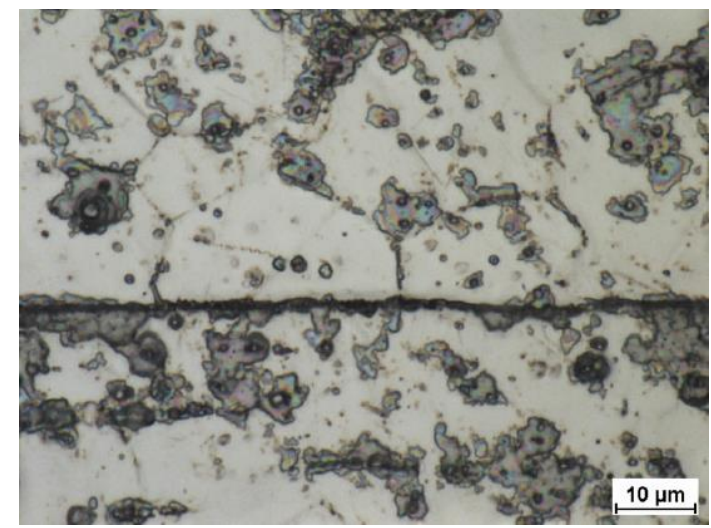

Fig. 2. Microstructure of the joint made at current value of $50 \%$ (magnification 1000x)



Fig. 3. Microstructure of the joint made at current value of $60 \%$ (magnification 1000×)

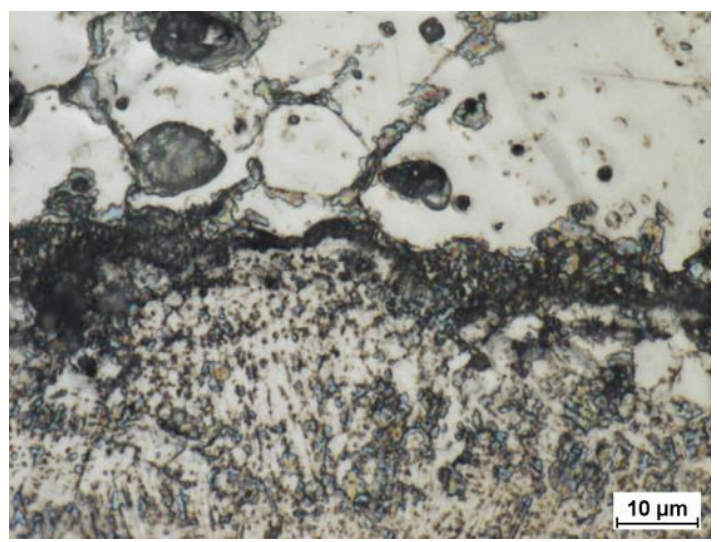

Fig. 4. Microstructure of the joint made at current value of $70 \%$ (magnification 1000x)

Samples were etched by means of electrolysis. Exemplary photographs of metallographic microstructures (observed on the Nikon Eclipse MA200 optical microscope with NIS 4.20 image analysis system) are shown in figs. $2-4$.

\section{Examination of micro-hardness distribution in the joint zone}

Micro-hardness tests according to Vicker's method were performed under the load of $100 \mathrm{G}(0.98 \mathrm{~N})$ for $15 \mathrm{~s}$. The average results of micro-hardness measurements in the joint material and thermal transfer zone (SWC) are presented in table III, and distribution of micro-hardness in fig. 5.

\section{TABLE III. Results of micro-hardness measurements}

\begin{tabular}{|c|c|c|c|}
\hline Pulsepowerlevel & $\begin{array}{c}\text { Hastelloy } \\
\text { XSWC, } \\
\text { HV 0.1 }\end{array}$ & JointHV 0.1 & $\begin{array}{c}\text { Haynes 230 } \\
\text { SWC, } \\
\text { HV 0.1 }\end{array}$ \\
\hline $50 \%$ & 232 & 278 & 260 \\
\hline $60 \%$ & 240 & 300 & 255 \\
\hline $70 \%$ & 239 & 290 & 253 \\
\hline
\end{tabular}

Analysis of the micro-hardness distribution of the micro-joint and the hardness in the zone of thermal transfer indicates that the parameters of the process were chosen correctly. With respect to the hardness of the native material, there was an increase in the hardness of the joint area and in the zone of thermal transfer. 


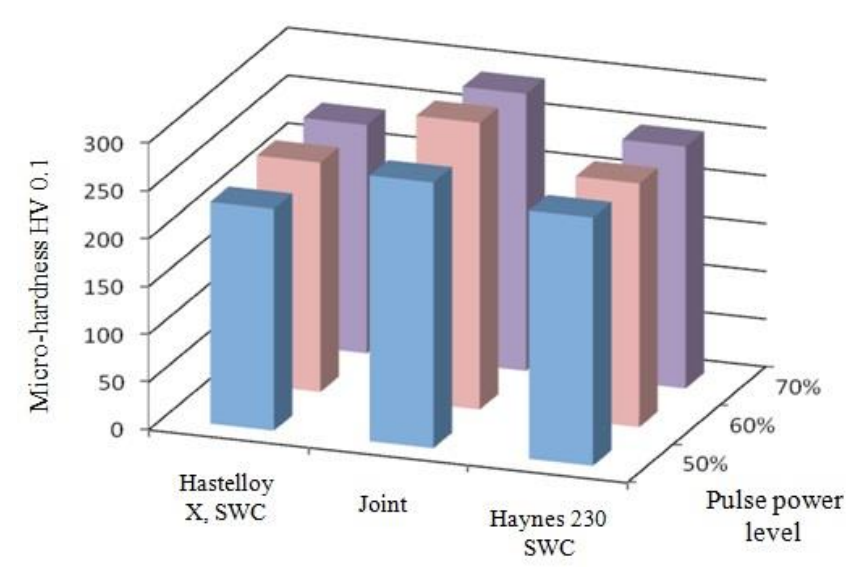

Fig. 5. Micro-hardness distribution in micro-welded joints of Hastelloy $X$ and Haynes 230 super-alloys and heat transfer zones
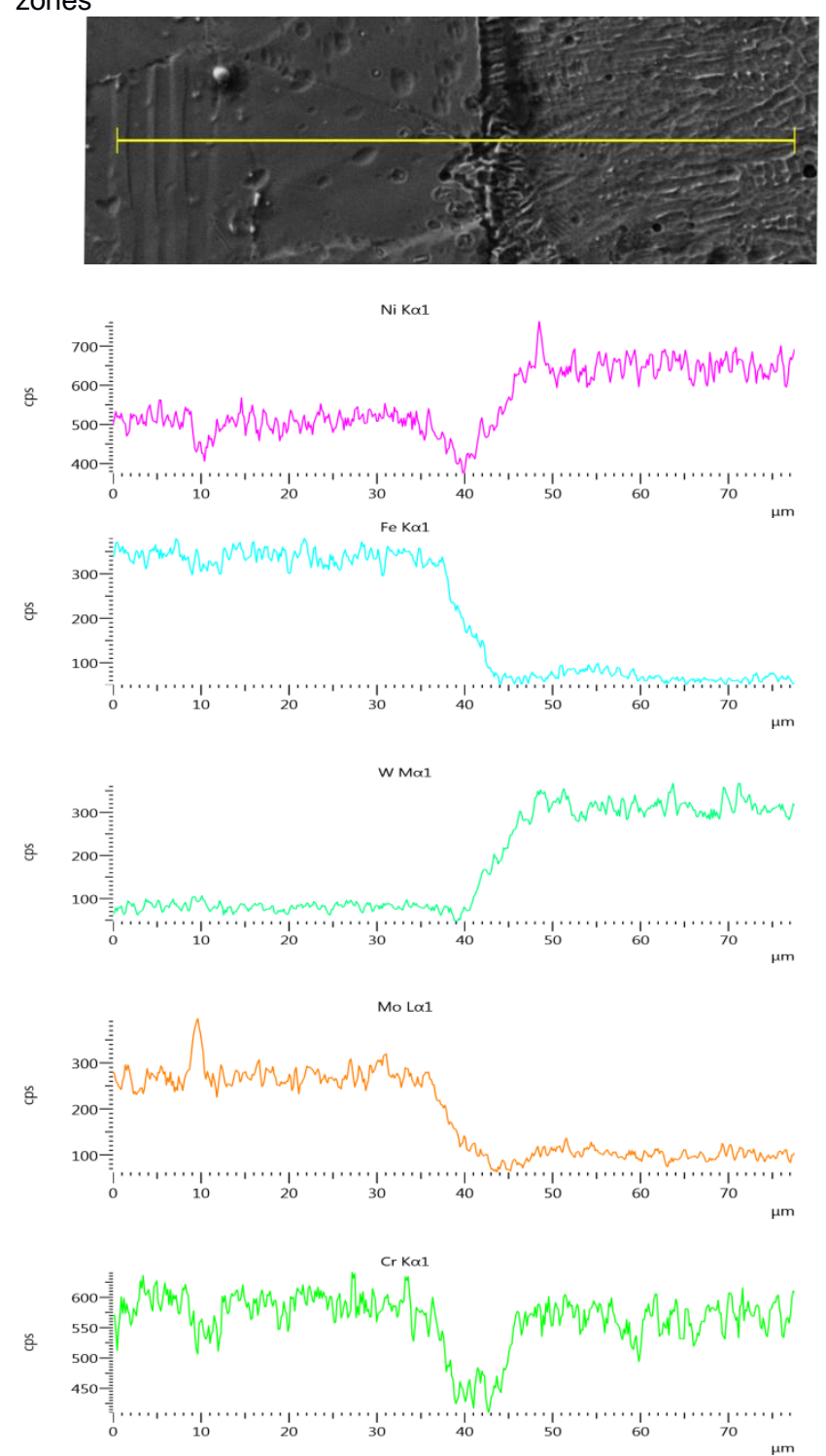

Fig. 6. Linear SEM analysis of chemical composition of welded joint of super-alloys Hastelloy $X$ and Haynes 230

\section{Linear analysis SEM of chemical composition}

The metallographic microstructure study was supplemented by linear analysis of the chemical composition. As a result, the distribution of selected elements (fig. 6) in the area of the joint. The analysis was carried out using OXFORD X-MAX electron microscope.

In the presented micro-photograph and graphs, the left side corresponds to the Hastelloy $X$ super-alloy, while the right - to Haynes 230.

\section{Conclusions}

The research has allowed for drawing the following conclusions:

- it is possible to obtain the correct joint, provided that high power parameters are used,

- micro-hardness tests for all samples confirmed the increase in hardness in the joint zone,

- no cracks in the area of the weld and the heat transfer zone,

- no modification was found in the joint - no diffusion of elements occurred.

\section{REFERENCES}

1. Dobranszky J. "The microwelding technologies and their applications". Budapest 2004.

2. Ruszaj A. "Nonconventional methods of machining machine elements and tools". Kraków: IOS, 1999.

3. Depczyński W., Młynarczyk P., Spadło S., Ziach E., Hepner $P$. "The selected properties of porous layers formed by pulse microwelding technique". Metal 2015: 24 ${ }^{\text {rd }}$ International Conference on Metallurgy and Materials, s. 1087-1092.

4. Młynarczyk P., Spadło S., Depczyński W., Śliwa E., Strzębski $P$. "The selected properties of the connection super alloy Haynes H 230 using microwelding title of paper". Metal 2015: $24^{\text {rd }}$ International Conference on Metallurgy and Materials, pp. 792-797.

5. Mucha Z., Widlaszewski J., Kurp P. i in. "Mechanicallyassisted laser forming of thin beams". Laser Technology 2016 : Progress and Applications of Lasers, Book Series: Proceedings of SPIE. 10159, Article No.101590U.

6. Napadlek W. "The impact of the output stereometry and absorbent coating on the efficiency of ablative laser texturing of iron alloy 100CrMn-Si6-4". Materials Testing. 57, 10 (2015): pp. 920-924.

7. Spadło S., Kozak J., Młynarczyk P. "Mathematical modelling of the electrical discharge mechanical alloying process". Proceedings of the Seventeenth CIRP Conference on Electro Physical and Chemical Machining (ISEM). 6 (2013): pp. 422426.

8. Młynarczyk P., Spadło S. "The Analysis of the Effects Formation Iron -Tungsten Carbide Layer on Aluminum Alloy by Electrical Discharge Alloying Process". Metal 2016: 25 Anniversary International Conference on Metallurgy and Materials, pp. 1109-1114.

9. Spadło S., Młynarczyk P., Depczyński W. "Investigation of the selected properties of superficial layer alloying with the tungsten electrodes". Metal 2015: $24^{\text {rd }}$ International Conference on Metallurgy and Materials, s. 863-867.

10. Oniszczuk D., Świercz R. "An investigation into the impact of electrical pulse character on surface texture in the EDM and WEDM process". Advances in Manufacturing Science and Technology. 36, 3 (2012): pp. 43-53.

11. Spadło S., Młynarczyk P. "Analysis of the Mechanical Interactions of the Filament Brush Electrode on the Formation of the Surface Roughness". Metal 2016: 25 $5^{\text {th }}$ Anniversary International Conference on Metallurgy and Materials, s. 11691174.

12. Krajewski A., Włosiński W., Chmielewski T., Kołodziejczak P., "Ultrasonic-vibration assisted arc-welding of aluminum alloys". Bulletin of the Polish Academy of Sciences: Technical Sciences. 60, 4 (2013): pp. 841-852. 
13. Chmielewski T., Golański D., Włosiński W. "Metallization of ceramic materials based on the kinetic energy of detonation waves". Bulletin of the Polish Academy of Sciences Technical Sciences. 63, 2 (2015): pp. 449-456.

14. Chmielewski T., Golański D. "New method of in-situ fabrication of protective coatings based on Fe-Al intermetallic compounds". Proceedings of the Institution of Mechanical Engineers. Part B: Journal of Engineering Manufacture. 225, 4 (2011): pp. 611-616.

15. Matuszewski M., Kałaczyński T., Łukasiewicz M., Musiał J. "Surface geometric structure after various treatments and wear process". The International Scientific Journal Problems of Tribology. 1 (2013): pp. 75-80.

16. Nabeel A., Chung H. "Alternating current-gas metal arc welding for application to thin sheets". Journal of Materials Processing Technology.214 (2014): pp. 1828-1837.

17. Shakil M., Tariq N.H., Ahmad M., Choudhary M.A., Akhter J.I., BabuS.S. "Effect of ultrasonic welding parameters on microstructure and mechanical properties of dissimilar joints". Materials and Design. 55 (2014): pp. 263-273.

18. Prasada K.S., Rao C.S., Rao D.N. "Effect of welding current mode on weld quality characteristics of pulsed current micro plasma arc welded AISI 304L sheets". Applied Mechanics and Materials. 465-466 (2014): pp. 1209-1213.

19. Operating instructions for microwelding WSS 7000S.

20. Hastelloy $X$ alloy information: www.haynesintl.com.

21. Haynes 230 alloy information: www.haynesintl.com.

22. Graneix J., Beguin J.-D., Pardheillan F., Alexis J., Masri T. "Weldability of the super alloys Haynes 188 and Hastelloy $X$ by Nd:YAG". MATEC Web of Conferences. 14, 13006 (2014). DOI 10.1051/matecconf/20141413006.

23. Qian S., Hong-Shuang D., Jun-Chen L., Xiao-Nan W. "Effect of pulse frequency on microstructure and properties of welded joints for dual phase steel by pulsed laser welding". Materials and Design. 105 (2016): pp. 201-211.

24. McDaniels R.L., Chen L., Steward R., Liaw P.K. i in. "The strain-controlled fatigue behavior and modeling of Haynes Hastelloy C-2000 super alloy". Materials Science and Engineering A. 528 (2011): pp. 3952-3960.

25. Lee S.Y., Lu Y.L., Liaw P.K. i in. "High-temperature tensilehold crack-growth behavior of Hastelloy $X$ alloy compared to Haynes 188and Haynes 230 alloys". Mechanics of TimeDependent Materials. 12(2008): pp. 31-44, DOI: 10.1007/s11043-008-9049-6.

26. Bulut Coskun M., Serdar Aksoy, Mahmut F. "Friction and Wear Characteristics of Haynes 25, 188, and 214 Superalloys Against Hastelloy $X$ up to $540^{\circ} \mathrm{C}^{\prime \prime}$. Tribology Letters. 45 (2012): pp. 497-503, DOI: 10.1007/s11249-011-9912-5.

27. Caiazzo F., Alfieri V., Sergi V., Schipani A., Cinque S. "Dissimilar autogenous disk-laser welding of Haynes 188 and Inconel 718 superalloys for aerospace applications". International Journal of Advanced Manufacturing Technology. DOI: 10.1007/s00170-013-4979-9.

28. BaghjariS.H., GhainiF.M., Shahverdi H.R., Ebrahimnia M., Mapelli C.,Barella S. "Characteristics of electro spark deposition of a nickel-based alloy on 410 stainless steel for purpose of facilitating dissimilar metal welding by laser". International Journal of Advanced ManufacturingTechnology. DOI: 10.1007/s00170-016-8668-3. 